\title{
Fumigant emission reductions with TIF warrant regulatory changes
}

\author{
by Husein Ajwa, Michael S. Stanghellini, \\ Suduan Gao, David A. Sullivan, Afiqur Khan, \\ William Ntow and Ruijun Qin*
}

With methyl bromide's phase-out, most growers have turned to alternative fumigants, particularly 1,3-dichloropropene (1,3-D) and chloropicrin. These alternatives are tightly regulated because they are classified as toxic air contaminants and volatile organic compounds; the latter combine with other substances to produce ground-level ozone (smog). Two ambient air monitoring studies were conducted to evaluate the potential of totally impermeable film (TIF) to reduce emissions from shank applications of chloropicrin and 1,3-D. In 2009, a study demonstrated that TIF reduced chloropicrin and 1,3-D peak emissions by $45 \%$ and $38 \%$, respectively, but TIF did not reduce total emissions when it was cut after 6 days. In 2011, increasing the tarp period from 5 to 10 days decreased chloropicrin and 1,3-D peak emissions by $88 \%$ and $78 \%$, and their total emissions by $64 \%$ and $43 \%$, respectively. Concurrent dynamic flux chamber results corroborated the ambient air monitoring data. These studies provide regulatory agencies with mitigation measures that should allow continued fumigant use at efficacious application rates.

A s the availability of methyl bromide diminishes, the use of products containing chloropicrin and 1,3-dichloropropene (1,3-D; Telone II) are becoming the new standard fumigant treatments. Various formulations of them are injected into the soil at depths of 8 to 24 inches using tractor-mounted injection shanks, or they are applied via chemigation, in a drip irrigation system.

$1,3-\mathrm{D}$ is an excellent nematicide with some broad-spectrum activity, and it is often applied as the sole active ingredient

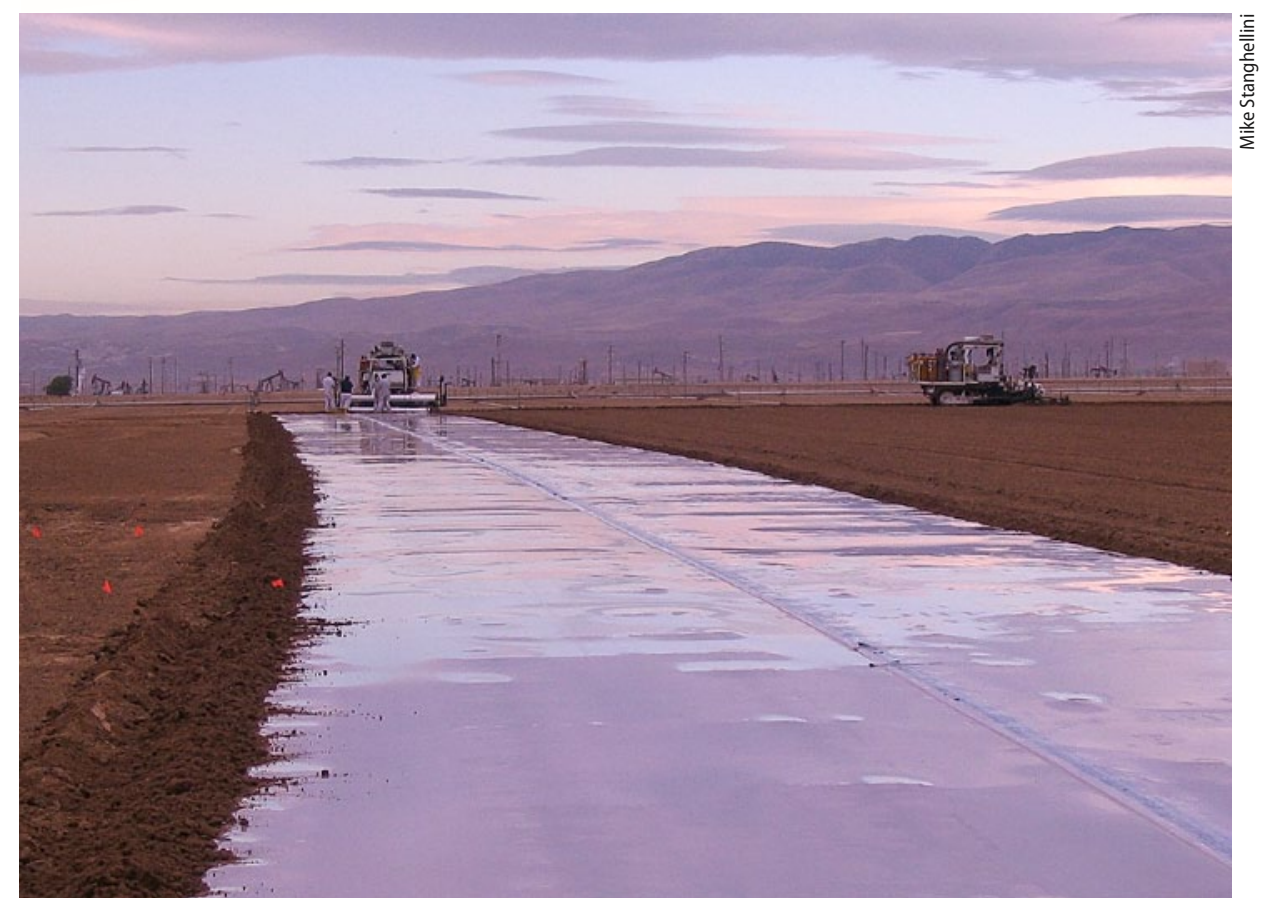

Recent studies demonstrate that totally impermeable film (TIF) can significantly reduce peak and total emissions of chloropicrin and 1,3-D when tarping periods are extended from 5 days to 10 days. Above, TIF application at Lost Hills, Kern County.

for crops that are primarily subject to nematode infestation. It is commonly combined with chloropicrin to enhance control of soilborne pathogenic fungi.

Chloropicrin has excellent fungicidal properties with some broad-spectrum activity, and it can be applied as the sole active ingredient for crops that are primarily under disease pressure. Chloropicrin is most often combined with either methyl bromide or 1,3-D to enhance control of other soil pests, such as nematodes and weeds.

1,3-D is regulated in California on a township cap basis (see page 122). Chloropicrin use, since December 2012, is restricted by U.S. Environmental Protection Agency (US EPA) buffer zone regulations; and all fumigants are limited by the California Department of Pesticide Regulation (DPR) in designated areas with air pollution problems. As part of the 2008 Reregistration Eligibility Decision (RED) for chloropicrin, the US EPA (2009) proposed substantial label changes for chloropicrin to mitigate potential exposure resulting from soil fumigation. The new requirements, which took full effect in December 2012, implement nationwide buffer zones for all chloropicrin products. Buffer zones are setback distances between a treated field and any occupied structure, designed to mitigate potential bystander exposure to peak emissions. Also in 2008, the California EPA (Cal EPA) Department of Pesticide Regulation (DPR) issued a series of regulations regarding volatile organic compound (VOC) emissions and subsequent limitations on how, when and where certain fumigants can be used (CDPR 2009). The DPR VOC regulations address cumulative amount of fumigant emissions over several days, rather than the highest emission value from treated fields; some fumigant VOC emissions react with nitrous oxide compounds (generated by vehicles, industrial processes, etc.) and contribute to ground-level ozone, a pollutant that affects the air quality in several air basins in California such as the Sacramento Valley, San Joaquin Valley, Southeast Desert, South Coast, and Ventura County. The regulations on

Online: http://californiaagriculture.ucanr.edu/ landingpage.cfm?article=ca.v067n03p147\&fulltext=yes doi: 10.3733/ca.v067n03p147 
fumigant-use patterns in these VOC nonattainment areas (NAAs) will continue to limit fumigant use in the NAAs.

Field trials conducted in the last few years have evaluated various surface sealing methods or treatments to reduce fumigant emissions during soil fumigation. These include different applica- film (TIF), contains an ethyl vinyl alcohol $(\mathrm{EVOH})$ resin vapor-barrier layer.

We collected field data from two trials to help regulatory agencies make decisions on the adoption of TIF for soil fumigation. We recorded peak emission levels, which are used to set buffer zones, and total emission levels, which relate to the VOC regulations. The trials

\section{The significant emissions reductions obtained when} using TIF should allow regulatory agencies to provide relief to growers.

tion methods, organic and chemical soil amendments, different tarping materials and supplemental irrigation (water seals) (e.g., Cabrera et al. 2011; Fennimore and Ajwa 2011; Gao et al. 2009, 2011). While several strategies effectively reduce fumigant emissions, some of them are impractical (e.g., lack of water precludes the use of water sealing) or may come at the expense of reduced efficacy if they impede the soil dispersion potential of the fumigant (Hanson et al. in press; Jhala et al. 2012).

The most promising and practical strategy, to date, appears to be the adoption of low-permeability tarps, collectively called virtually impermeable films (VIFs). Traditional VIFs contain a nylon vaporbarrier layer; a relatively new type of lowpermeability film, totally impermeable mixtures of the two (coformulated enduse products).

\section{Materials and methods}

We conducted two field trials to evaluate the potential of TIF to reduce fumigant peak and total emissions: the first in 2009 near Oxnard, Ventura County, and the second in 2011 near Lost Hills, Kern County. Both sites were located in air basins designated by DPR as VOC nonattainment areas (NAAs), where fumigant use is restricted (see page 122).

All fields were prepared in accordance with the product-labeled mandatory good agricultural practices (GAPs), which are a suite of application guidelines on proper soil preparation, appropriate soil moisture, weather considerations, application parameters and other factors. The test

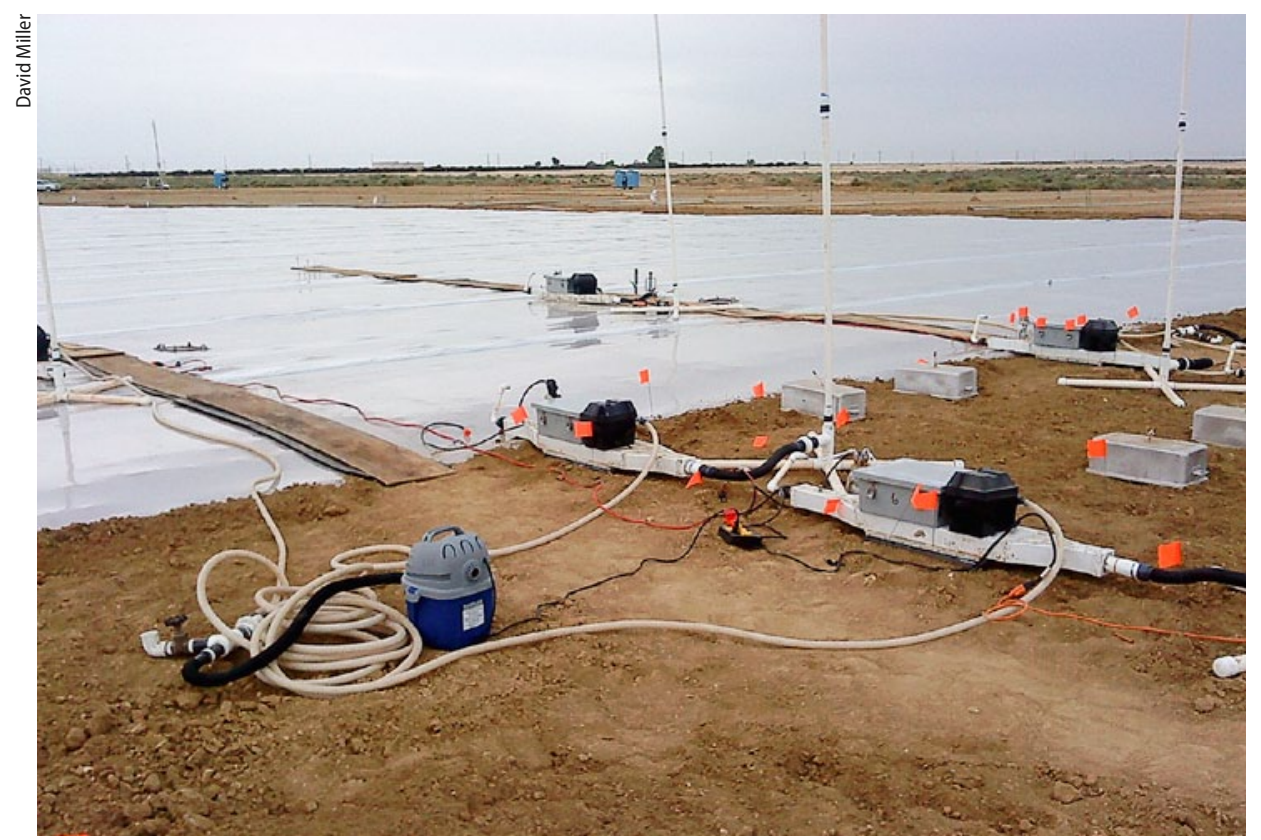

To monitor fumigant emissions at ground level, researchers used dynamic flux chamber equipment, above, to confirm and interpret the ambient air monitoring data.

field plots were chosen to reflect representative sandy loam California fumigated soils, typical seasons of application and typical application equipment.

In both trials, chloropicrin and 1,3-D emissions from the broadcast fields were determined by measuring ambient air concentrations in 8 to 16 directions (depending on field size and shape) surrounding the field. Measurements were recorded for 6-hour periods for the first 48 hours, then every 12 hours for the remainder of the study except during tarp cutting and removal, when the sampling reverted to 6-hour intervals.

Air was pumped through ANASORB CSC (coconut charcoal; SKC tube 226-109) and XAD-4 solid sorbent tubes to capture any 1,3-D and chloropicrin, respectively, in the air at each sampling period. Chloropicrin and 1,3-D were extracted from the respective sorbent tubes using analytical methods developed by the CDFA, and both were analyzed by gas chromatography using a micro electron capture detector. The Industrial Source Complex (ISCST3) Dispersion Model was used to determine chloropicrin and 1,3-D flux values using the analytical results coupled with concurrent meteorological data that were collected during air monitoring. On-site meteorological stations collected relevant data, including wind speed, wind direction, ambient air temperature, relative humidity, solar radiation and precipitation.

Fumigant permeation through TIF was also determined using the dynamic flux chamber method, whereby flowthrough chambers were placed directly on top of the TIF. A constant air flow through the chamber swept the air above the tarp, allowing fumigant emissions passing through the tarp to be trapped at the chamber outlet using XAD-4 resin sampling tubes; these tubes were later extracted and analyzed using gas chromatography with a micro electron capture detector. The dynamic flux chamber was operated continuously, with 3- to 6-hour intervals between exchanging sampling tubes.

Flux was calculated based on fumigant concentration captured in the chamber, sampling area, sampling time and flow rate. Detailed chamber methodology information can be found in Gao and Wang (2011). The dynamic flux chamber method monitors fumigant emissions at ground 
level (the tarp-air interface) and was used to help confirm and interpret the ambient air monitoring data - in particular, it increased our confidence in data collected from large fields.

The polyethylene tarp used was a standard commercial broadcast tarp (1-mil high-barrier film by Cadillac Products Packaging Company, Troy, MI) that complied with the methyl bromide tarp permeability requirements of Title 3, California Code of Regulations, Section 6450(e). The TIF, VaporSafe, was manufactured by Raven Industries (Sioux Falls, SD). In the 2009 trial, the TIF used was an experimental 10.5-foot-wide film. In 2011, the TIF was a 13-foot-wide commercially viable film.

\section{Oxnard trial}

Two broadcast application fields, approximately 1 acre each, were separated by several miles to prevent cross-contamination. Air sampling was conducted at the beginning of each application (Sept. 10) and continued for 13 days (Sept. 23). Tarp cutting occurred 6 days after application (Sept. 16). An experimental 50:50 mixture of chloropicrin and 1,3-D was applied in both fields via broadcast shank at a 12-inch injection depth and at a rate of 281.2 pounds of product per acre in Field 1 and 275.0 pounds per acre in Field 2. Field 1 was tarped with 10.5 -foot-wide, 1-mil, clear polyethylene film. Field 2 was

TABLE 1. Broadcast shank application scenarios in ambient air monitoring field trials in Oxnard 2009 and Lost Hills 2011

\begin{tabular}{|c|c|c|c|c|c|}
\hline Location & Field & $\begin{array}{l}\text { Soil sealing } \\
\text { method }\end{array}$ & $\begin{array}{l}\text { Days to } \\
\text { tarp cut }\end{array}$ & $\begin{array}{l}\text { Injection } \\
\text { depth }\end{array}$ & $\begin{array}{l}\text { Formulated product* } \\
\text { application rate }\end{array}$ \\
\hline & & & & inches & Ib/acre \\
\hline Oxnard & 1 & Polyethylene & 6 & 12 & $\begin{array}{c}\text { Pic-Clor } 50 \\
281.2\end{array}$ \\
\hline Oxnard & 2 & TIF & 6 & 12 & $\begin{array}{c}\text { Pic-Clor } 50 \\
275.0\end{array}$ \\
\hline Lost Hills & 1 & TIF & 16 & 12 & $\begin{array}{c}\text { Pic-Clor } 60 \\
571.3\end{array}$ \\
\hline Lost Hills & 2 & TIF & 10 & 12 & $\begin{array}{c}\text { Pic-Clor } 60 \\
547.0\end{array}$ \\
\hline Lost Hills & 3 & TIF & 5 & 12 & $\begin{array}{c}\text { Pic-Clor } 60 \\
593.6\end{array}$ \\
\hline
\end{tabular}

tarped with 10.5-foot-wide, 1-mil, clear TIF (table 1).

A certified applicator applied the fumigants using a closed, pressurized, winged shank injection system (Noble plow). Soil type in Field 1 (polyethylene tarp) was a Hueneme sandy loam (coarse loamy, mixed, superactive, calcareous, thermic Oxyaquic Xerofluvents). Soil type in Field 2 (TIF) was a Metz loamy sand (sandy, mixed, thermic Typic Xerofluvents).

\section{Lost Hills trial}

This study was designed to determine the effectiveness of TIF in reducing emission rates and total mass loss of

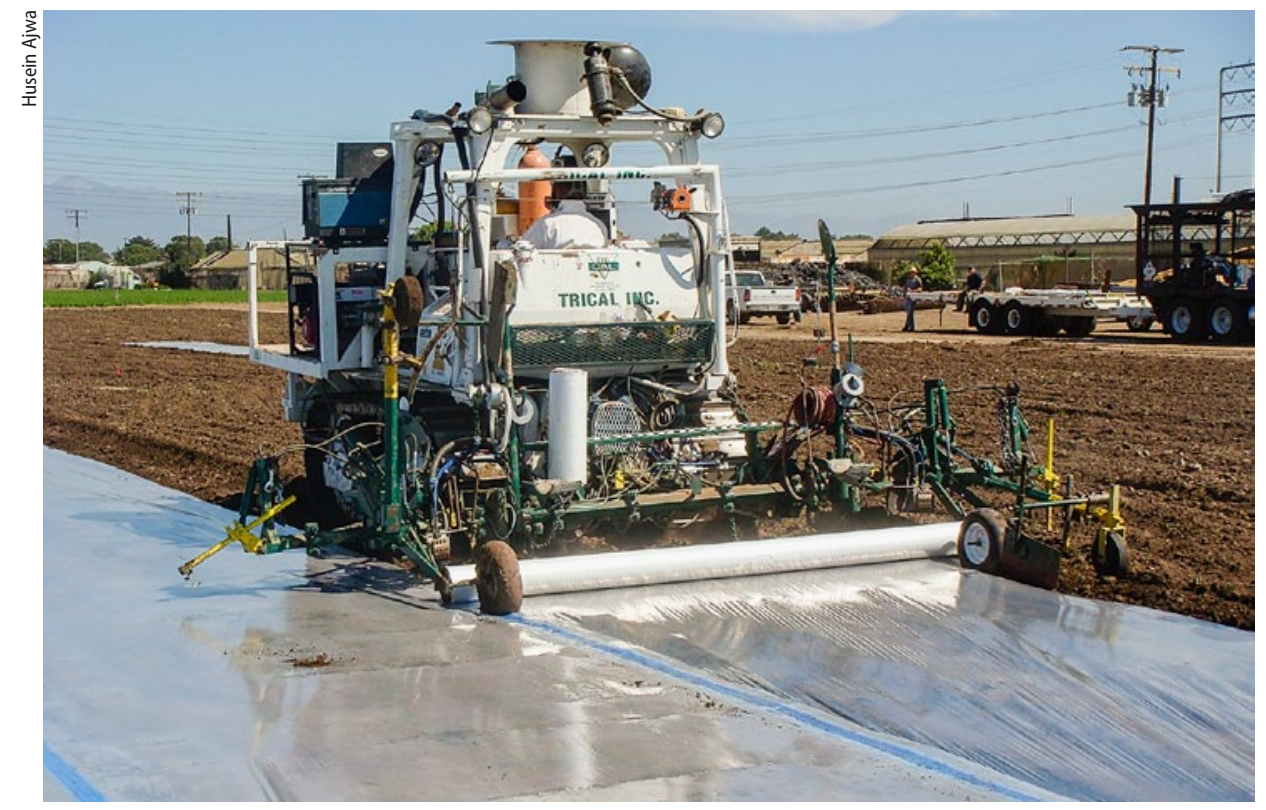

Data from the Oxnard trial indicate that a longer tarp-covering period than the standard 5 days is needed to reduce emissions associated with tarp cutting. Above, broadcast shank fumigation under TIF, Oxnard, Ventura County, September 2009. chloropicrin and 1,3-D and to show the extent that peaks associated with tarp cutting change as a function of tarp deployment period. Comparative emissions data were generated from three 12-inch-deep broadcast shank applications of a 60:40 chloropicrin and 1,3-D co-formulated enduse product (Pic-Clor 60). The three fields were in close proximity to one another to enable concurrent air monitoring and to ensure that meteorological and soil conditions were similar.

The applications were made on one 8 -acre field (Field 1) and two 2-acre fields (Fields 2 and 3) near Lost Hills on June 4. The two 2-acre fields were separated by approximately 830 feet to prevent crosscontamination. The 8-acre field was at least 4,900 feet from the other fields. Air monitoring was conducted concurrently at each field starting at the beginning of application and continuing until 48 hours after the time of tarp cutting in each field. All fields had the same application scenario: Pic-Clor 60 applied via broadcast shank at a 12-inch injection depth with a target rate of 588 pounds of product per acre (equivalent to 350 pounds chloropicrin per acre plus 238 pounds 1,3-D per acre).

Soil type in all three fields was Milham sandy loam (fine loamy, mixed, superactive, thermic Typic Haplargids) except for one corner of Field 1, which contained Kimberlina fine sandy loam (coarse loamy, mixed, superactive, calcareous, thermic Typic Torriorthents).

The only major difference between the three fields was the duration of tarp deployment. Field 1 was tarped for 16 days, 
Field 2 for 10 days, and Field 3 for 5 days (table 1).

\section{Oxnard trial results}

Background samples collected at both fields indicated that no cross-contamination occurred during the monitoring. For Field 1 (polyethylene tarp) and Field 2 (TIF), the chloropicrin peak flux rates were $8.31 \mu \mathrm{g} / \mathrm{m}^{2} /$ second at 162 to 168 hours after the start of application, and $4.62 \mu \mathrm{g} / \mathrm{m}^{2} /$ second at 0 to 6 hours after the start of application, respectively (fig. 1A). Total mass loss of chloropicrin was $10.8 \%$ in Field 1 and $14.1 \%$ in Field 2 (fig. 1B). Field 2's total mass loss may have been affected by the numerous holes inadvertently punched into the tarp during air monitoring by unknown personnel working in adjacent fields.

The 1,3-D peak flux rates in Field 1 were $38.28 \mu \mathrm{g} / \mathrm{m}^{2} / \mathrm{second}$ at 30 to 36 hours after the start of application; and in Field 2, they were $28.53 \mu \mathrm{g} / \mathrm{m}^{2} /$ second at 144 to 150 hours after the start of application (fig. 1C). Total mass loss of 1,3-D was $43.24 \%$ in Field 1 and $42.9 \%$ in Field 2 (fig. 1D).

Emission flux and cumulative loss estimated using dynamic flux chambers were reported in Qin et al. 2011. Emission flux of chloropicrin and 1,3-D from Field 2 (TIF) was substantially lower than from Field 1 (polyethylene film) during tarp covering. Total through-film emission loss during the 6-day covered period was $<1 \%$ for chloropicrin and $2 \%$ for $1,3-\mathrm{D}$ in Field 2 compared to $12 \%$ for chloropicrin and $43 \%$ for $1,3-\mathrm{D}$ in Field 1 . The greater retention of 1,3-D under the TIF (Field 2) resulted in an emissions peak after tarp cutting, which did not occur with the polyethylene film (Field 1). Chloropicrin emissions were fairly low in both fields, regardless of the tarp type.

Overall, the dynamic flux chamber data were similar to the ambient monitoring data in figure 1, which show there was no difference between the TIF and polyethylene tarped fields in terms of total emission loss. The data clearly indicate that a longer tarp-covering period than the standard 5 days would be needed to reduce emissions associated with tarp cutting.

These results demonstrate that while in place and intact (and in comparison to polyethylene tarp), TIF can significantly reduce the peak emissions rates of chloropicrin and 1,3-D. However, longer tarping periods are needed to achieve optimal reduction in total emissions of $1,3-\mathrm{D}$.

\section{Lost Hills trial results}

No cross-contamination between fields occurred during the air sampling periods. For Field 1 (tarped with TIF for 16 days), the chloropicrin peak emissions rate was $6.46 \mu \mathrm{g} / \mathrm{m}^{2} /$ second at approximately 48 to 60 hours after the start of the application (fig. 2A); for Field 2 (TIF for 10 days), it was $5.12 \mu \mathrm{g} / \mathrm{m}^{2} /$ second at approximately 72 to 84 hours after the start of the application; and for Field 3 (TIF for 5 days), it was $41.53 \mu \mathrm{g} / \mathrm{m}^{2} /$ second at approximately 126 to 132 hours after the start of the application (fig. 2A). The total mass loss
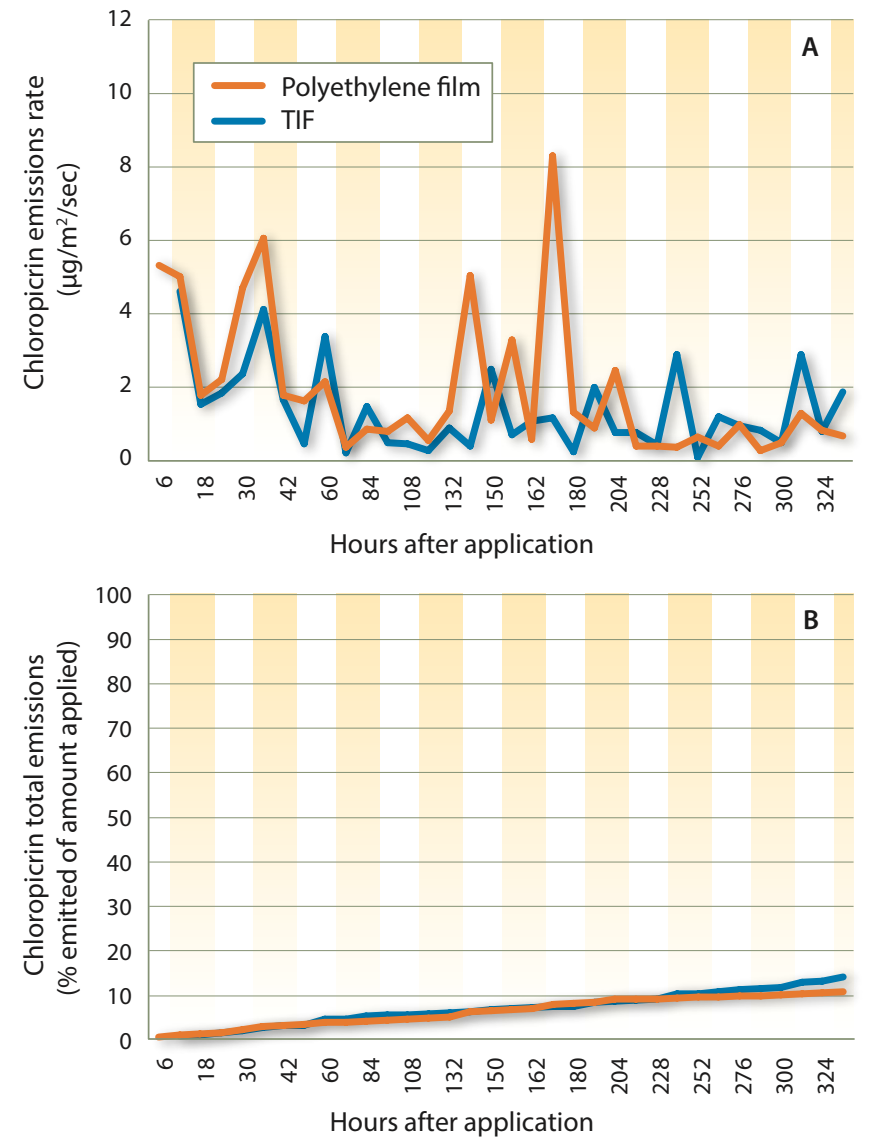
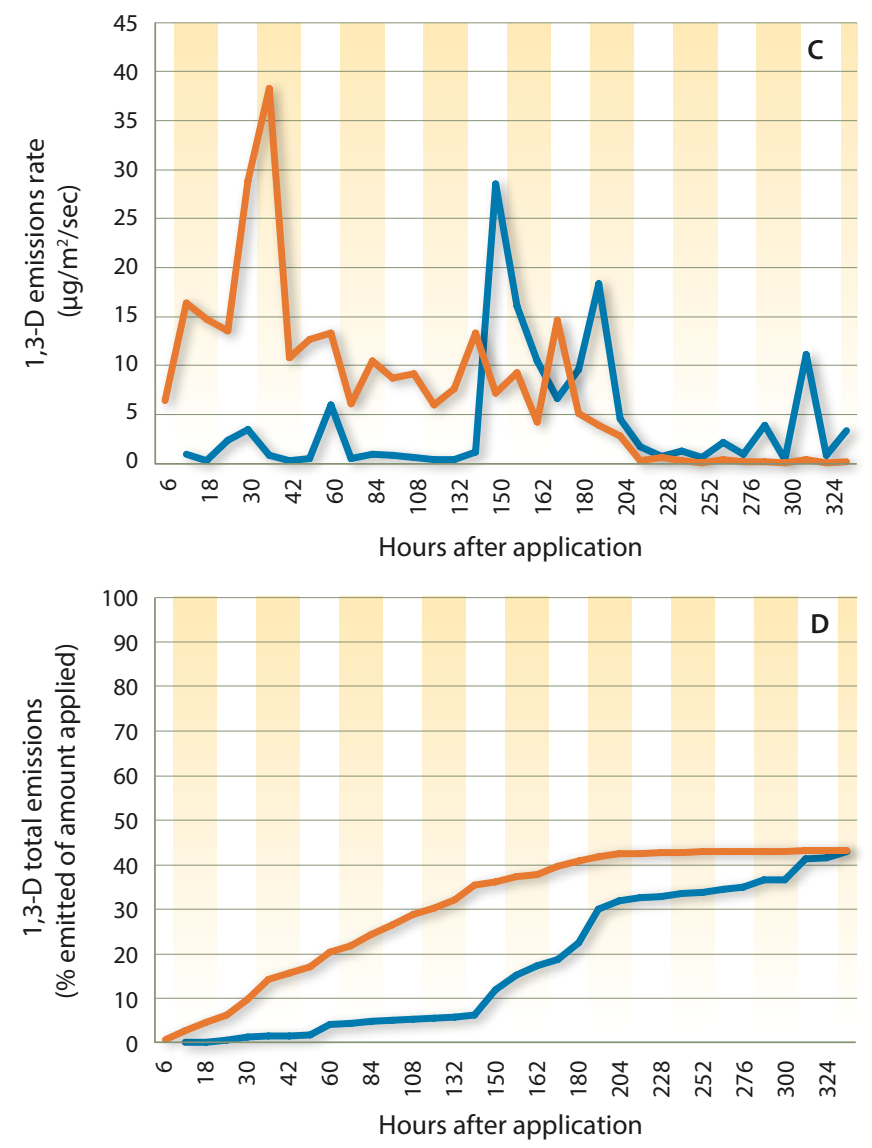

Fig. 1. Peak and total emissions from the Oxnard 2009 trial as measured by ambient air monitoring. (A) Chloropicrin emissions rate; (B) Chloropicrin total emissions; (C) 1,3-D emissions rate; and (D) 1,3-D total emissions. 
for chloropicrin was 4.5\% (Field 1), 3.6\% (Field 2) and 10.0\% (Field 3) (fig. 2B).

For Field 1 (TIF for 16 days), the 1,3-D peak emissions rate was $6.49 \mu \mathrm{g} / \mathrm{m}^{2} / \mathrm{sec}$ ond at approximately 30 to 36 hours after the start of the application (fig. 2C); for Field 2 (TIF for 10 days), it was $10.63 \mu \mathrm{g}$ / $\mathrm{m}^{2} /$ second at approximately 246 to 252 hours after the start of the application; and for Field 3 (TIF for 5 days), it was 47.29 $\mathrm{\mu g} / \mathrm{m}^{2} /$ second at approximately 126 to 132 hours after the start of the application (fig. 2C). The total mass loss for 1,3-D was 10.2\% (Field 1), 10.9\% (Field 2) and 19.1\% (Field 3) (fig. 2D).

Emission flux and total emission loss measured in Field 1 by the dynamic flux chamber method are shown in figure 3 (A-D). Over the 16-day tarp period, cumulative emission losses before tarp cutting were $5.7 \%$ for chloropicrin and $7.4 \%$ for $1,3-\mathrm{D}$, respectively (fig. 3B, 3D). A much smaller emissions rate was measured after tarp cutting on this 16-day tarped field than was measured in the 2009 trial, where the TIF was cut after
6 days. Emission losses resulting from tarp cutting in the 2011 trial were 2.1\% for chloropicrin and 5.6\% for 1,3-D, respectively. The total measured emission losses from Field 1 in the 2011 study were $7.8 \%$ for chloropicrin and $13.1 \%$ for $1,3-\mathrm{D}$. These measurements generally support the ambient monitoring results $(4.5 \%$ loss of applied chloropicrin and $10.2 \%$ loss of applied 1,3-D).

The results of the Lost Hills study demonstrated that peak and total emissions of chloropicrin and 1,3-D under TIF are significantly lower when tarp cutting is extended from 5 days to 10 days. The differences in total emissions when tarps were cut at 10 days versus 16 days after application were negligible.

\section{Significant emission reductions}

While in place and intact (deployed in the field), TIF significantly reduces fumigant emissions by retaining fumigants under the tarp. These studies corroborate and provide field-scale validation of earlier laboratory work showing the emissions reduction potential of this film technology. For fumigants like chloropicrin with short soil half-lives (1 to 2 days), a tarping period of 5 to 6 days should be sufficient for application rates of less than 200 pounds per acre. However, for higher application rates and for fumigants with longer soil half-lives, such as 1,3-D, longer tarp periods are needed to maximize the emissions reduction potential of TIF use.

These results show that peak and total emissions arising from high rates of chloropicrin and 1,3-D applications can be effectively mitigated if the tarping duration of TIF is extended to 10 days. Only nominal benefits would be achieved by extending the tarping period from 10 to 16 days. Although TIF has the ability to retain 1,3-D in the soil for a few weeks, the degradation half-life of 1,3-D under field conditions is 5 to 7 days (Ajwa et al. 2003, 2010), and a very small residual concentration, if any, is found in the soil when TIF is removed from the field after 10 days. Also, the final degradation products of 1,3-D are nontoxic (mainly carbon dioxide,
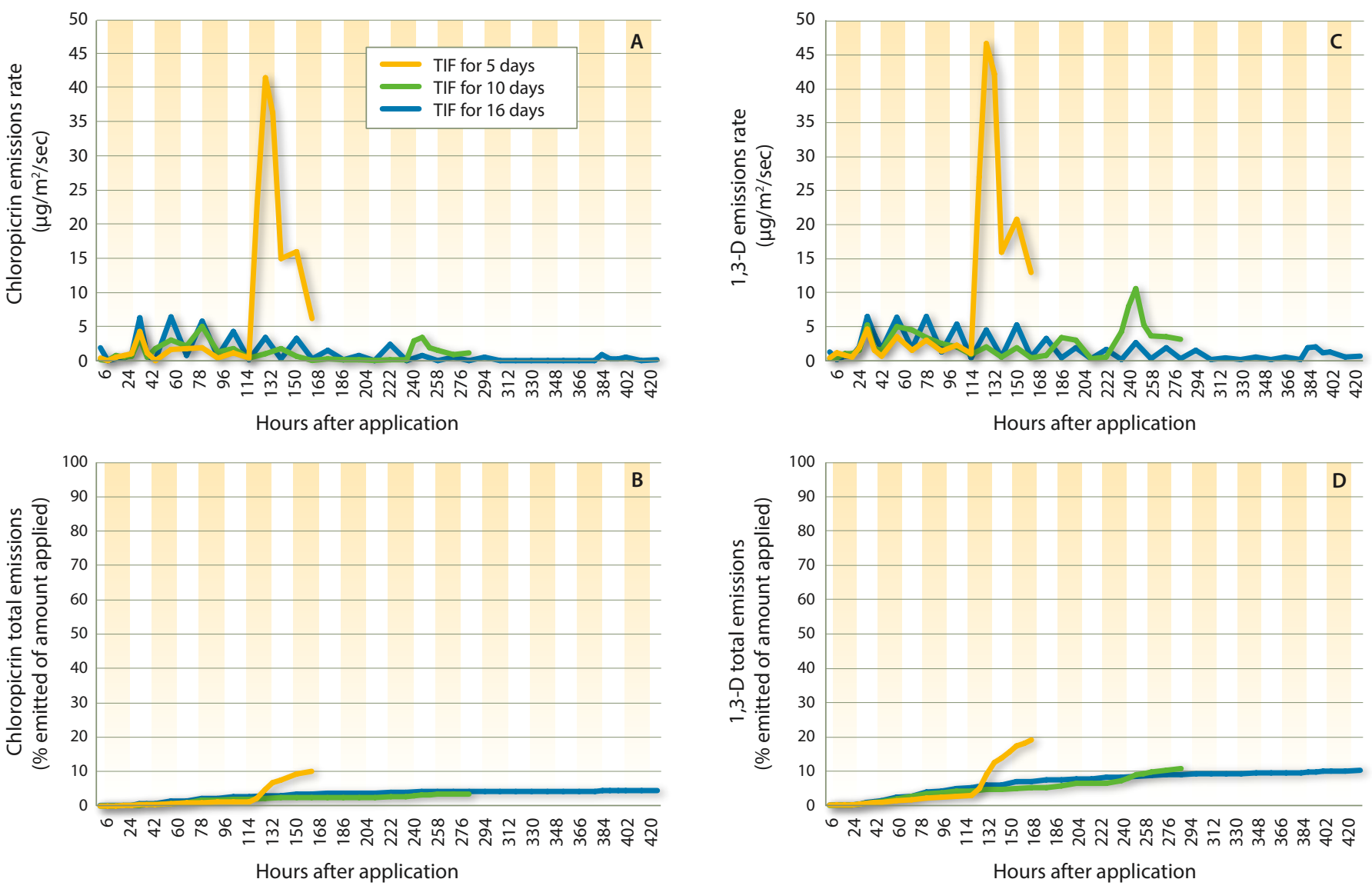

Fig. 2. Peak and total emissions from Lost Hills 2011 trial as measured by ambient air monitoring. (A) Chloropicrin emissions rate; (B) Chloropicrin total emissions; (C) 1,3-D emissions rate; and (D) 1,3-D total emissions. 
water and chlorine) and do not pose risk to humans and the environment (Dungan and Yates 2003).

Emission data obtained from dynamic flux chambers agree with and strongly support the ambient monitoring data. The significant emissions reductions obtained when using TIF should allow regulatory agencies to provide relief to growers by implementing smaller buffer zones, increasing the volume of fumigant use and providing growers with greater flexibility in areas with spatially or temporallybased fumigant restrictions where total emissions are of concern.

H. Ajwa is UC Cooperative Extension Soil and Plant Specialist, UC Davis; M.S. Stanghellini is Research Scientist, TriCal, Inc.; S. Gao is Soil Scientist, USDA-ARS; D.A. Sullivan is Certified Consulting Meteorologist, Sullivan Environmental Consulting, Inc.; A. Khan is Postdoctoral Scholar, UC Davis; W. Ntow is Postdoctoral Scholar, UC Davis; and R. Qin is Assistant Project Scientist, UC Davis.*

*"R. Quin" was corrected to "R. Qin" after press run.

\section{References}

Ajwa HA, Klose S, Neilson SD, et al. 2003. Alternatives to methyl bromide in strawberry production in the United States of America and the Mediterranean Region. Phytopathol Mediterr 42:220-44

Ajwa H, Ntow WJ, Qin R, Gao S. 2010. Properties of soil fumigants and their fate in the environment. In: Krieger $\mathrm{R}$ (ed.). Hayes' Handbook of Pesticide Toxicology. San Diego: Elsevier Inc. p 315-30.

Cabrera JA, Hanson BD, Abit MJM, et al. 2011. Efficacy of 1,3-dichloropropene plus chloropicrin reduced rates under two different tarps against nematodes, pathogens and weeds. In: Proc Ann Int Res Conf on MeBr Alternatives and Emission Reductions, Oct. 31-Nov. 2, 2011. San Diego, CA

[CDPR] California Department of Pesticide Regulation 2009. Volatile Organic Compound (VOC) Emissions from Pesticides. www.cdpr.ca.gov/docs/emon/vocs/vocproj/ vocmenu.htm.

Dungan RS, Yates SR. 2003. Degradation of fumigant pesticides: 1,3-dichloropropene, methyl isothiocyanate, chloropicrin and methyl bromide. Vadose Zone J 2:279-86

Fennimore SA, Ajwa H. 2011. Totally impermeable film retains fumigants, allowing lower application rates in strawberry. Calif Agr 65(4):211-5.

Gao S, Hanson BD, Wang D, et al. 2011. Methods evaluated to minimize emissions from pre-plant soil fumigation. Calif Agr 65(1):41-6.
Gao S, Qin R, Hanson BD, et al. 2009. Effects of manure and water applications on 1,3-dichloropropene and chloropicrin emission in a field trial. J Agric Food Chem 57:5428-34.

Gao S, Wang D. 2011. Chapter 9: Vapor flux measurements - Chamber methods. In: Saponaro S, Sezenna E, Bonomo L (eds.). Vapor Emission to Outdoor Air and Enclosed Spaces for Human Health Risk Assessment: Site Characterization, Monitoring and Modeling. Hauppauge, NY: Nova Science Publishers. p 191-207.

Hanson BD, Gao S, Gerik J, et al. 2013. Preplant 1,3-D treatments test well for perennial crop nurseries, but challenges remain. Calif Agr 67(3): In press. doi: 10.3733/ ca.E.v067n03p181

Jhala AJ, Gao S, Gerik JS, et al. 2012. Effects of surface treatments and application shanks on nematode, pathogen and weed control with 1,3-dichloropropene. Pest Manag Sci 68:225-30.

Qin R, Gao S, Ajwa H, et al. 2011. Field evaluation of a new plastic film (Vapor Safe) to reduce fumigant emissions and improve distribution in soil. J Environ Qual 40:1195-203.

[US EPA] U.S. Environmental Protection Agency. 2009. Implementation of Risk Mitigation Measures for Soil Fumigant Pesticides. www.epa.gov/oppsrrd1/ reregistration/soil_fumigants/\#ammendedreds.
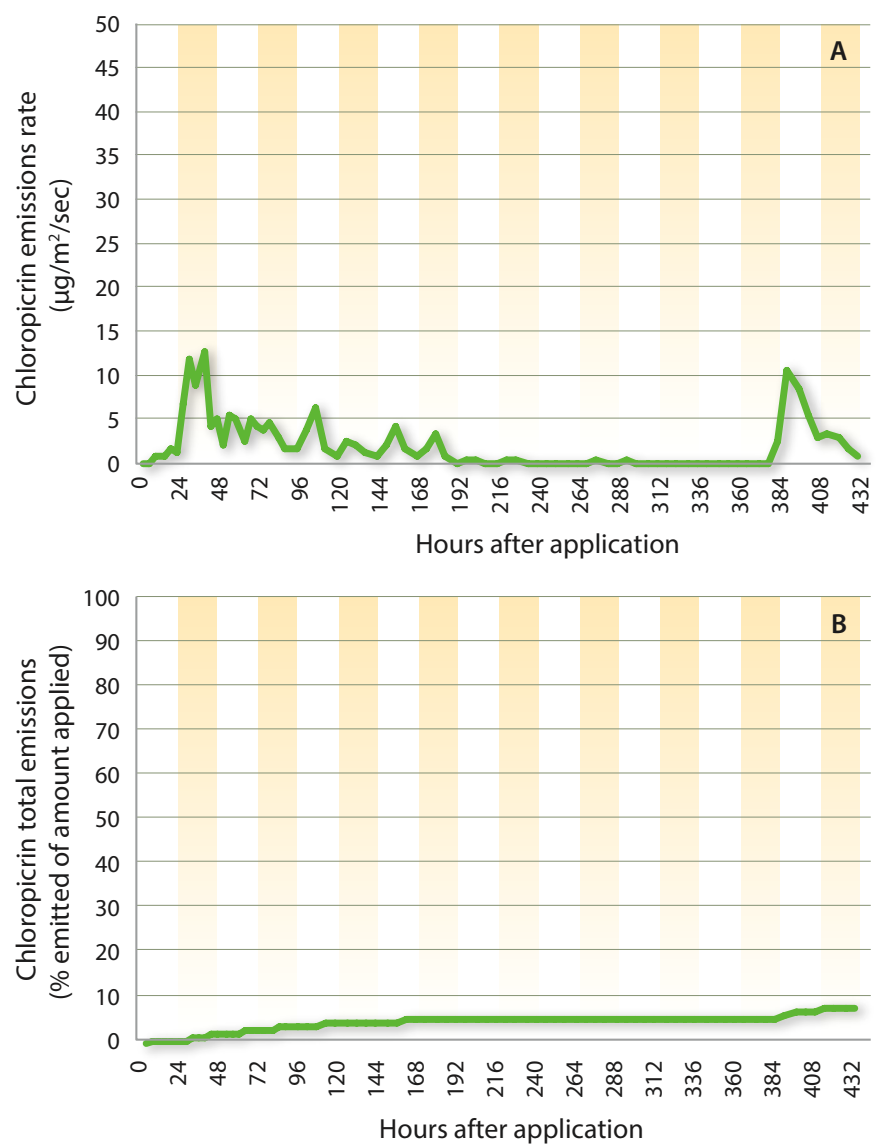
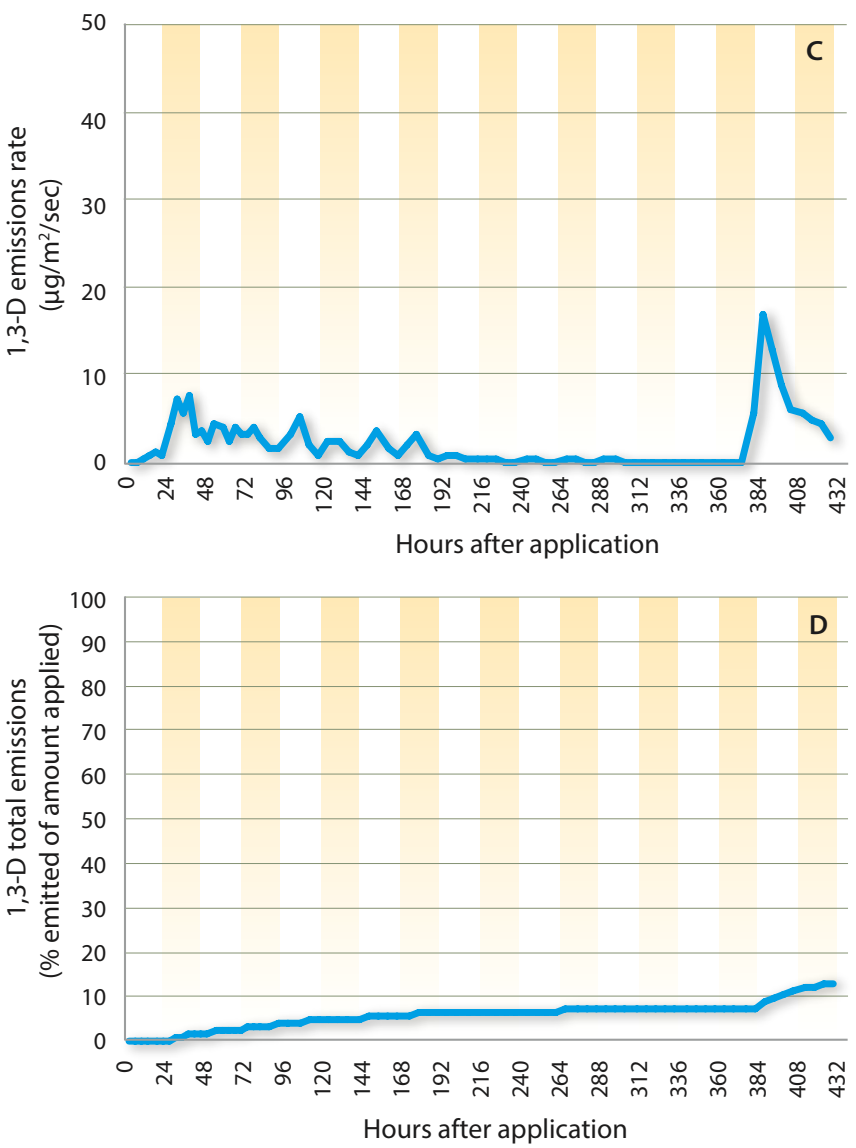

Fig. 3. Peak and total emissions from Field 1 (16 days) of Lost Hills 2011 trial as measured by the dynamic flux chamber. (A) Chloropicrin emissions rate; (B) Chloropicrin total emissions; (C) 1,3-D emissions rate; and (D) 1,3-D total emissions. 